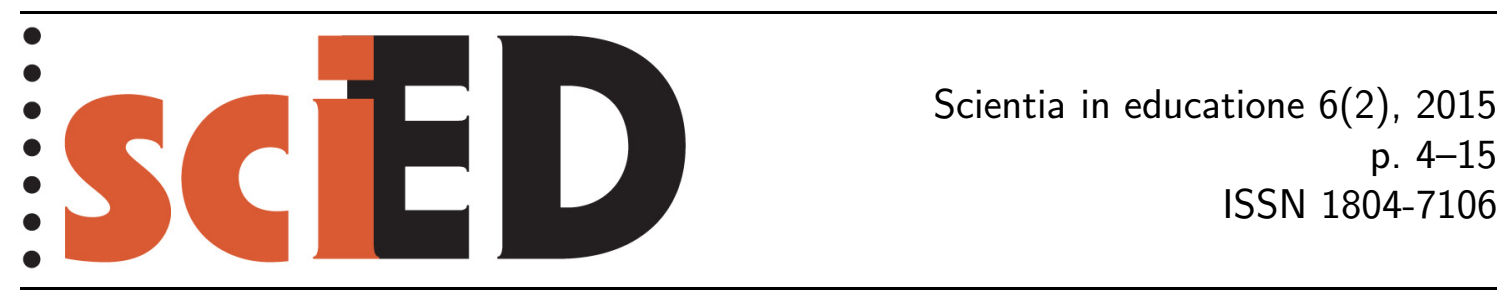

\title{
Disertační práce se zaměřením na didaktiku biologie v České republice v letech 2004-2013
}

\author{
Lenka Pavlasová
}

\begin{abstract}
Abstrakt
Disertační práce je důležitým ukazatelem kvality doktorského studia. V předložené studii byl proveden kvalitativní výzkum 19 disertačních prací z didaktiky biologie obhájených v období let 2004-2013 metodou obsahové analýzy. Byly zkoumány tyto ukazatele: oborové téma, stupeň zkoumané školy, metody sběru dat při výzkumu, počet autocitací a jejich kvalita, př́padný praktický výstup do praxe a jeho charakter. Autory prací byly z $64 \%$ ženy a z 36 \% muži. Oborová témata byla zastoupena nevyváženě, některá byla zcela opomíjena (např. biologie hub). V pracích byly zkoumány všechny stupně školy: preprimární, primární, nižší a vyšší sekundární a vysokoškolský (0-3 a 5-6 podle ISCED97). Hlavní metodou sběru dat byl dotazník, následovaný obsahovou analýzou dokumentů, pozorováním, didaktickým testem a interview. Počet vlastních prací autora citovaných v disertační práci byl značně kolísavý. Práce, které obsahovaly malé množství autocitací, obsahovaly většinou ještě praktický výstup (didaktickou aplikaci) a nebyly výlučně výzkumné.
\end{abstract}

Klíčová slova: disertační práce, didaktika biologie, doktorské studium.

\section{Doctoral Theses Focused on Didactics of Biology in the Czech Republic between Years 2004-2013}

\begin{abstract}
Doctoral theses are an important indicator of the quality of doctoral studies. In this study, qualitative research of 19 dissertations focused on the didactics of biology defended between years 2004-2013 was conducted by the content analysis method. The following indicators were followed: biological topics, educational level under examination, methods of data collection used in research, number of auto-citations and their quality, practical output and its characteristics. There were $64 \%$ female authors of dissertations and $36 \%$ men authors. Biological topics were unequally represented, some of them were completely neglected (e.g., biology of fungi). All educational levels were examined in the analysed dissertations: pre-primary, primary, lower and upper secondary and university levels $(0-3$, 5-6 according to ISCED97). The most frequently used method of data collection in doctoral students' research was a questionnaire, followed by the content analysis, observations, an achievement test and an interview. The number of auto-citations in dissertations was varied. Dissertations with a small number of auto-citations usually contained some kind of a practical output and thus, they were not entirely only research ones.
\end{abstract}

Key words: doctoral thesis, didactics of biology, doctoral studies. 
Vývoj didaktiky biologie v českých zemích je neodmyslitelně spojen i s problematikou výzkumu v této vědní disciplíně a s kvalifikačním růstem odborníků, kteří v této oblasti působí. Klíčovou roli zde hrají v první řadě doktorské studijní programy. Těmto tématům je proto obvykle v konferenčních příspěvcích i přehledových článcích věnováno důležité místo (Dostál, 2010, 2014; Ušáková, 2014; Papáček et al., 2015). Stejnou pozornost věnuje doktorskému studiu i Akreditační komise ČR, která provedla v letech 2010-2013 hodnocení kvality doktorských programů na vysokých školách v ČR (Dvořáková \& Smrčka, 2013). Komise se mimo jiné věnovala i disertačním pracím a úrovni publikační činnosti absolventů jako jednomu ukazateli kvality doktorského studia. Konstatovala, že v posledních letech lze vidět zvyšující se nároky na kvalitu prací a publikační činnost doktorandů a školitelů. Největšími potenciálními faktory, které snižují úroveň disertačních prací, je nedostatečné personální zabezpečení vedení těchto prací (interní a externí školitelé, konzultanti), neujasněnost koncepce výzkumu na jednotlivých pracovištích a nepropojení tohoto výzkumu s tématy disertačních prací (Dvořáková \& Smrčka, 2013). Tato konstatování jsou obecná a týkají se samozřejmě i prací zaměřených na didaktiky přírodních věd.

Výzkum, popisovaný $\mathrm{v}$ této stati, je součástí společného projektu hodnotícího vybrané parametry (ukazatele kvality) v disertačních pracích v oblasti didaktiky biologie, fyziky (Žák, 2015) a chemie (Rusek, 2015).

Výzkum disertačních prací z didaktiky biologie je zaměřen na období uplynulých zhruba deseti let. Uvedený interval spadá do doby, kdy byly disertační práce obhajovány v oboru Pedagogika. Didaktika biologie neměla absolventy ze svého vlastního akreditovaného oboru ${ }^{1}$ (srov. s tab. 1). Je proto zajímavé se podívat, která témata byla v pracích zkoumána, jaká v nich byla používána metodologie a kterému stupni vzdělávání byla věnována. Celý výzkum se snaží být př́íspěvkem k určité reflexi v jednom segmentu úkolů, které jsou náplní oboru didaktika biologie (Pavlasová, 2014), a tou je kvalifikační růst nositelů tohoto oboru. Zaměřuje se na oblast doktorského studia a z něj si vybírá analýzu výstupů doktorského studia, disertačních prací. Problematiku řeší v kontextu didaktiky biologie samotné, ovšem s vědomím, že obdobně zaměřené články na didaktiku fyziky (Žák, 2015) a chemie (Rusek, 2015) pomohou čtenáři učinit si komplexnější závěr.

Jako základní ukazatele kvality prací byly zvoleny použité metody sběru dat a četnost a kvalita autorovy publikační činnosti. Volba těchto kritérií vychází ze stanoviska Akreditační komise ČR, která ve své souhrnné zprávě uvádí, že „posláním doktorského programu je náročná individuální vědecká příprava s důrazem na metodologii vědy a schopnost realizace základního výzkumu“ (Dvořáková \& Smrčka, 2013: s. 401). Kromě těchto ukazatelů byly zkoumány i jiné doplňující údaje, které nám umožní lépe porozumět celkovému kontextu vzniku a zaměření prací (oborové téma, stupeň školy, pohlaví autorů, jazyk práce, př́ítomnost jiných než výzkumných výstupů práce).

Hlavním cílem provedeného výzkumu bylo odpovědět na následující otázky:

- Která oborová témata jsou v disertačních pracích zkoumána?

- Který stupeň vzdělávání je v disertačních pracích zkoumán?

- Které metody sběru dat používají autoři disertačních prací při svém výzkumu?

- Jaká je četnost a kvalita autorovy publikační činnosti (posuzováno počtem vlastních publikací autora uvedených v disertační práci)?

- Jak často a v jaké podobě se v pracích vyskytují „vedlejší produkty“ výzkumu (konkrétní praktické aplikace)?

\footnotetext{
${ }^{1}$ Obor Vzdělávání v biologii je akreditován od r. 2010, ale v době psaní článku neměl ještě žádného absolventa.
} 
Tab. 1: Vysoké školy v ČR s akreditovanými studijní programy s možností zaměření na didaktiku biologie

\begin{tabular}{lll}
\hline Vysoká škola (fakulta) & Studijní program & Studijní obor \\
\hline $\begin{array}{l}\text { Univerzita Karlova v Praze } \\
\text { (Pedagogická fakulta) }\end{array}$ & Pedagogika & Pedagogika* \\
\hline $\begin{array}{l}\text { Masarykova univerzita v Brně } \\
\text { (Pedagogická fakulta) }\end{array}$ & Pedagogika & Pedagogika \\
\hline $\begin{array}{l}\text { Univerzita Palackého v Olomouci } \\
\text { (Pedagogická fakulta) }\end{array}$ & Pedagogika & Pedagogika \\
\hline $\begin{array}{l}\text { Univerzita Karlova v Praze } \\
\text { (Pedagogická fakulta) }\end{array}$ & Pedagogika & Vzdělávání $^{\text {Jihočeská univerzita v Ceských Budějovicích }}$ \\
(Př́rodovědecká a Pedagogická fakulta) & & v biologii** \\
\hline
\end{tabular}

*Z rozhodnutí vědecké rady Pedagogické fakulty Univerzity Karlovy v Praze do tohoto oboru již nejsou nově přijímáni studenti se specializací na didaktiku biologie, studium dokončuje několik posledních studentů s tímto zaměřením.

**Akreditován od r. 2010.

\section{Metodologie}

Použitý výzkum je kvalitativní, výzkumnou metodou je obsahová analýza dokumentu (Hendl, 2005). Práce byly zkoumány z hlediska těchto stanovených kritérií: oborové téma, stupeň zkoumané školy, metody sběru dat při výzkumu, počet vlastních publikací autora uvedených v disertační práci a jejich kvalita a př́padný praktický výstup do praxe a jeho charakter. Pro přehlednost byly výsledky některých těchto parametrů kvantifikovány. Práce byly analyzovány podle jejich dostupnosti bud' v listinné nebo elektronické podobě.

Do výzkumu byly zařazeny všechny didakticky orientované práce z vědních oborů tvořících obsah vyučovacích předmětů prvouka a přírodověda na 1. stupni ZS̆, př́ŕrodopis na 2. stupni ZŠ a biologie a geologie na SS̆ a práce vztahující se ke vzdělávacím oblastem Dítě a jeho tělo a Dítě a svět v preprimárním vzdělávání (RVP PV, 2006; RVP G, 2007; RVP ZV, 2013; Pavlasová, 2014) v časovém intervalu let 2004-2013. Uvedený časový interval byl zvolen zejména z toho důvodu, aby bylo možné v budoucnu komparovat zjištěné údaje s údaji v publikaci Žáka (2015) a Ruska² (2015), a tím poskytnout jisté srovnání úrovně disertací v didaktice fyziky, chemie i biologie. Druhým důvodem bylo, že v tomto období neměla didaktika biologie svůj samostatně akreditovaný obor a práce byly obhajovány pouze ve studijním oboru Pedagogika. Proto se jevilo potřebné toto období reflektovat a shrnout, k čemuž by mohla analýza disertací přispět. Třetím důvodem byla možnost porovnání s obecnými závěry ve zprávě Akreditační komise (Dvořáková \& Smrčka, 2013), která se věnovala hodnocení doktorského studia v období do r. 2013. Seznam analyzovaných disertačních prací je uveden $\mathrm{v}$ př́lloze.

\footnotetext{
${ }^{2}$ Rusek (2015) do své analýzy zahrnuje i rok 2014. V tomto roce nebyla obhájena žádná práce z didaktiky biologie, proto naše analýza fakticky končí rokem 2013.
} 


\section{VÝSLEDKY}

\section{ZÁKLADNÍ ÚDAJE O DISERTAČNÍCH PRACÍCH}

V období 2004-2013 bylo v České republice obhájeno celkem 22 prací (viz tab. 2), z nichž bylo analyzováno 19, tedy $86 \%$. Zbývající tři práce nebyly analyzovány $\mathrm{z}$ toho důvodu, že se je nepodařilo dohledat $\mathrm{v}$ knihovně ${ }^{3}$, př́padně nebyly dostupné on-line ${ }^{4}$. Všechny práce byly napsány v českém jazyce.

Tab. 2: Počet prací v jednotlivých letech (celkem 22)

\begin{tabular}{lcccccccccc}
\hline Rok & 2004 & 2005 & 2006 & 2007 & 2008 & 2009 & 2010 & 2011 & 2012 & 2013 \\
\hline počet & 4 & 2 & 1 & 3 & 1 & 4 & 2 & 1 & 2 & 2 \\
\hline
\end{tabular}

Z tab. 2 je patrné, že počty disertačních prací obhájených v jednotlivých letech jsou v podstatě stabilní a jedná se pouze o jednotky prací. Počet autorek versus počet autorů je $14: 8$, tj. $64 \%$ žen a $36 \%$ mužůn.

\section{OBOROVÉ TÉMA PRÁCE}

Přehled oborových témat, kterými se práce zabývají, ukazuje tab. 3. Oborová témata byla tř́děna do hlavních skupin podle tematických okruhů vzdělávacího oboru Př́irodopis ve Vzdělávací oblasti Člověk a příroda, uvedených v RVP ZV (2013). Toto zjednodušené tř́idění bylo zvoleno i pro př́ípady, že se práce netýkaly vzdělávání na 2. stupni základních škol.

Tab. 3: Oborové zaměření analyzovaných disertačních prací (celkem 19)

\begin{tabular}{lcl}
\hline Oborové téma & Počet prací & Poznámka (rok obhájení) \\
\hline Obecná biologie a genetika & 1 & 2007 \\
\hline Biologie hub & 0 & - \\
\hline Biologie rostlin & 1 & 2013 \\
\hline Biologie živočichů & 3 & $2004,2007,2009$ \\
\hline Biologie člověka & 1 & 2013 \\
\hline Ekologie & 5 & $2004,2009,2012,2010(2 \times)$ \\
\hline Neživá príroda & 1 & 2007 \\
\hline Jiné/více témat současně & 7 & $2004,2006,2008,2009(2 \times), 2011,2012$ \\
\hline
\end{tabular}

Z tab. 3 je zřejmé, že větši část prací $(12$, tj. $63 \%$ ) z celkových 19 byla oborově úžeji zaměřena. Nejčastěji řešená témata prací se vztahovala $\mathrm{k}$ ekologii, př́padně environmentalistice, což není př́liš překvapivé vzhledem k zájmu, který je ekologii a environmentalistice nejen ve vzdělávání, ale i ve společnosti po r. 1990 věnován. Menší část prací (37 \%) zpracovávala téma obecnější, případně více témat současně,

\footnotetext{
${ }^{3}$ Böhnisch, Robin: Př́rodní poměry Hrádečku a jejich využití ve výuce (rok obhájení 2005, Pedagogická fakulta UK v Praze).

${ }^{4}$ Jůvová (roz. Zachová), Alena: Didaktická vybavenost učebnic př́rodopisu v kontextu environmentální edukace, (rok obhájení 2004, Pedagogická fakulta Masarykovy univerzity) a Škrabánková (roz. Vančurová), Jana: Obsahová dimenze kurikula vzdělávání učitelů přírodovědných předmětů na 2. stupni ZŠ a SS̆ (rok obhájení 2005, Pedagogická fakulta Masarykovy univerzity).
} 
z nichž žádné nebylo dominující, a snažila se na problematiku výuky přírodovědných předmětů dívat komplexněji. $\mathrm{V}$ tab. 3 najdeme i roky, kdy byly práce na daná témata obhájeny. $\mathrm{Z}$ nich ale nelze vzhledem $\mathrm{k}$ malému počtu analyzovaných prací a krátkému, desetiletému, intervalu, ze kterého byly práce zkoumány, vyvodit žádný obecný závěr, který by vypovídal o tendencích v oblibách témat. Mưžeme ale konstatovat, že zastoupení oborů, jejichž didaktické aspekty jsou v pracích řešeny, je poměrně nevyrovnané.

\section{STUPEŇ ک̌KOLY}

Analyzované práce se zabývaly všemi stupni vzdělávání, od předškolního až po vysokoškolské (viz tab. 4). Nejvíce je v disertačních pracích zkoumáno vysokoškolské vzdělávání (bakalářské i magisterské). Dále je poměrně často zkoumáno primární vzdělávání (1. stupeň ZŠ) a vzdělávání sekundární (nižší i vyšší). Relativně nejméně se autoři prací věnují preprimárnímu vzdělávání, což může být způsobeno tím, že preprimární vzdělávání má svá specifika a realizované výzkumy bývají více komplexní a neomezují se na izolovaná témata z didaktik přírodních věd. Žádná ze zkoumaných prací se nezabývá neformálním vzděláváním. Z tab. 4 vyplývá, že žádný stupeň školy není v tématech prací nějak výrazně opomíjen a všechny se zabývají pouze formální vzděláváním.

Tab. 4: Stupeň zkoumané školy

v disertačních pracích

(celkem 19 prací)

\begin{tabular}{|c|c|c|}
\hline$\overline{\text { Stupeň školy (ISCED97) }}$ & $\begin{array}{l}\text { Počet } \\
\text { prací }\end{array}$ & $\begin{array}{c}\text { Relativní } \\
\text { četnost }\end{array}$ \\
\hline Mateřská škola (0) & 2 & $11 \%$ \\
\hline$\overline{\text { 1. stupeň ZS (1) }}$ & 4 & $21 \%$ \\
\hline 1. a 2. stupeň ZS $(1,2)$ & 1 & $5 \%$ \\
\hline 2. stupeň Z Ž (2) & 3 & $16 \%$ \\
\hline 2. stupeň Z Z a SS $(2,3)$ & 1 & $5 \%$ \\
\hline$\overline{\mathrm{SS}}(3)$ & 2 & $11 \%$ \\
\hline$\overline{\mathrm{SS}}$ a VŠ $(3,5,6)$ & 1 & $5 \%$ \\
\hline$\overline{\mathrm{VS}(5,6)}$ & 5 & $26 \%$ \\
\hline jiné & 0 & - \\
\hline
\end{tabular}

\section{METODY SBĚRU DAT}

Návrh výzkumného plánu a volba vhodných metod výzkumu je základní předpoklad pro úspěšný průběh př́ípravy disertační práce. Zatímco výzkumný plán a údaje o typu výzkumu byly v pracích v některých př́ípadech obtížně dohledatelné, metody sběru dat se daly poměrně jasně identifikovat. Při jejich tř́iění jsme vycházeli z charakteristiky popsané Chráskou (2007) a Hendlem (2005). Zastoupení metod sběru dat $\mathrm{v}$ disertačních pracích je uvedeno v tab. 5 .

V každé disertační práci byla použita nejméně jedna metoda sběru dat. Nejpoužívanější metodou je jednoznačně dotazník, který najdeme v 74 \% všech prací. Koresponduje to i s častým použiváním této metody v bakalářských a diplomových pracích, které vycházejí z autorčiny osobní zkušenosti. Další poměrně oblíbenou metodou je obsahová analýza nejrůznějších dokumentů. Vyskytuje se v $53 \%$ pracích. Pozorování je využíváno především při výzkumech v předškolním a primárním vzdělávání, celkem bylo použito v $37 \%$ pracích. Didaktický test a inteview jsou vyžívány s nejmenší četností. Ve zkoumaných pracích jsme nezaznamenali žádnou jinou použitou metodu. 
Tab. 5: Metody sběru dat v disertačních pracích (celkem 19 prací)

\begin{tabular}{lccc}
\hline Metoda sběru dat & $\begin{array}{c}\text { Počet prací } \\
\text { obsahujících } \\
\text { metodu* }\end{array}$ & $\begin{array}{c}\text { Relativní } \\
\text { četnost } \\
\text { ze všech } \\
\text { metod }\end{array}$ & $\begin{array}{c}\text { Relativní } \\
\text { četnost } \\
\text { ze všech } \\
\text { prací }\end{array}$ \\
\hline Dotazník & 14 & $34 \%$ & $74 \%$ \\
\hline $\begin{array}{l}\text { Obsahová analýza dokumentů (např. textů, } \\
\text { učebnic, kurikulárních dokumentů, prací } \\
\text { žáků) }\end{array}$ & 10 & $24 \%$ & $53 \%$ \\
\hline Pozorování & 7 & $18 \%$ & $37 \%$ \\
\hline Didaktický test & 5 & $12 \%$ & $26 \%$ \\
\hline Interview (včetně skupinové diskuse) & 5 & $12 \%$ & $26 \%$ \\
\hline Jiná & 0 & - & - \\
\hline Žádná & 0 & - & - \\
\hline
\end{tabular}

*V pracích byla použivána většinou kombinace různých metod. Pokud byla daná metoda použita v práci ve více variantách (např. více typů dotazníků), byla započítána jen jednou na danou práci.

\section{POČET VLASTNÍCH PUBLIKACÍ AUTORA A JEJICH KVALITA}

Kvalita publikační činnosti je jedna z podstatných podmínek úspěšné obhajoby doktorské disertační práce (Ušáková, 2014). Zároveň je to i ukazatel kvality celého doktorského studia (Dvořáková \& Smrčka, 2013). Z tohoto důvodu byl hodnocen i počet autocitací v analyzovaných pracích. Z 19 analyzovaných prací se v 9 případech (tj. $47 \%$ ) nevyskytovala $\mathrm{v}$ práci ani jedna autocitace (do této skupiny jsme zařadili i práce, kde byla citována pouze autorova diplomová práce). Ve zbylých 10 pracích je počet autocitací velmi kolísavý, což je patrné z tab. 6 .

Tab. 6: Počet autocitací v disertačních pracích (10 prací)

\begin{tabular}{ccccr}
\hline Práce č. & $\begin{array}{c}\text { Počet } \\
\text { autocitací RIV }\end{array}$ & $\begin{array}{c}\text { Počet } \\
\text { autocitací neRIV }\end{array}$ & $\begin{array}{c}\text { Vystoupení } \\
\text { na konferenci }\end{array}$ & Celkem \\
\hline 1 & - & 1 & - & 1 \\
\hline 2 & 2 & 15 & 4 & 21 \\
\hline 3 & 1 & - & - & 2 \\
\hline 4 & - & 1 & 8 & 1 \\
\hline 5 & 5 & 5 & 2 & 18 \\
\hline 6 & 2 & 4 & - & 8 \\
\hline 7 & - & 3 & 15 & 3 \\
\hline 8 & 1 & - & - & 16 \\
\hline 9 & - & 6 & 13 & 6 \\
\hline 10 & - & 3 & 43 & 92 \\
\hline Celkem & 11 & 38 & &
\end{tabular}

\section{PRAKTICKÝ VÝSTUP PRÁCE}

V disertačních pracích z didaktiky biologie je častá př́tomnost různých výstupů do praxe, at̉ už se jedná o výukové materiály, vysokoškolská skripta, inovace kurzů, 
návrhy koncepcí výuky apod. Autoři se tedy bohužel mnohdy nevěnují pouze výzkumu, který by měl být hlavní náplní doktorského studia, ale v disertacích popisují i možnosti aplikace svých výsledků v praxi, nebo případně do ní zařazují jimi vytvořené opory pro realizaci změn ve výuce založených na provedeném výzkumu. Ze zkoumaných 19 prací jich takovou část obsahovalo 10 (tj. 53 \%). Konkrétně se jednalo o návrh námětů na exkurze, tvorbu tematických plánů a školního vzdělávacího programu konkrétní školy na základě provedeného výzkumu, o inovace obsahu vysokoškolského kurzu na základě provedeného výzkumu, různé výukové materiály (včetně vysokoškolských skript, celkem ve 2 pracích), dále o návody na výrobu didaktických pomůcek a návody na využití tématu ve výuce, návrh opatření pro efektivní př́ipravu studentů v didaktice věcného učení, návrh Rámcového vzdělávacího programu pro obor vzdělávání s maturitní zkouškou Ekologie a životní prostředí, vytvoření konceptu environmentální výchovy na 1. stupni ZŠ a inovace vzdělávacího programu vysoké školy na základě provedeného výzkumu. Přítomnost praktického výstupu v práci jsme zaznamenali pouze u prací obhájených do r. 2009 (tab. 7).

Zajímavý, ale $\mathrm{v}$ podstatě logický vztah mezi př́itomností praktického výstupu v práci a počtem autocitací nám ukazují tab. 7 a 8. Práce s praktickým výstupem obsahovaly méně citovaných vlastních publikací autora než práce, které byly věnovány výlučně výzkumu. Navíc se ve skupině prací s didaktickou aplikací vyskytuje i více prací, kde není uvedena ani jedna autocitace. V obou skupinách můžeme ale najít dvě práce, které se počtem autocitací vymykají směrem nahoru.

Tab. 7: Počet autocitací v pracích s praktickým výstupem (10 prací)

\begin{tabular}{lccccccccccc}
\hline C. práce & 1 & 2 & 3 & 4 & 5 & 6 & 7 & 8 & 9 & 10 & celkem \\
\hline $\begin{array}{l}\text { Rok } \\
\text { obhájení }\end{array}$ & 2004 & 2006 & 2007 & 2007 & 2007 & 2008 & 2009 & 2009 & 2009 & 2009 & - \\
\hline $\begin{array}{l}\text { Počet } \\
\text { autocitací }\end{array}$ & 0 & 0 & 2 & 0 & 0 & 16 & 0 & 1 & 0 & 18 & 37 \\
\hline
\end{tabular}

Tab. 8: Počet autocitací v pracích pouze výzkumných (bez praktického výstupu, 9 prací)

\begin{tabular}{lcccccccccc}
\hline C. práce & 1 & 2 & 3 & 4 & 5 & 6 & 7 & 8 & 9 & celkem \\
\hline $\begin{array}{l}\text { Rok } \\
\text { obhájení }\end{array}$ & 2004 & 2004 & 2010 & 2010 & 2011 & 2012 & 2012 & 2013 & 2013 & - \\
\hline $\begin{array}{l}\text { Počet } \\
\text { autocitací }\end{array}$ & 1 & 21 & 6 & 0 & 0 & 8 & 3 & 0 & 16 & 55 \\
\hline
\end{tabular}

\section{DiskUSE}

Předmětem uvedeného výzkumu byly vybrané parametry, pomocí nichž jsme chtěli ilustrovat úroveň disertačních prací z didaktiky biologie $\mathrm{v}$ posledních zhruba deseti letech. Jsme si vědomi toho, že výběr zkoumaných kritérií byl poměrně úzký, proto by tento výzkum bylo možné určitě rozšíríit.

Počet prací obhájených v letech 2004-2013 je v porovnání s jejich počtem v didaktice fyziky (61 prací, Žák, 2015) a didaktice chemie (38 prací, Rusek, 2015) mnohem nižší. Každý rok se jednalo jen o jednotky prací, jejichž počet nebyl vyšší než čtyři. Důvodem je s největší pravděpodobností to, že práce vznikaly v oboru 
Pedagogika na rozdíl od prací z didaktiky fyziky a didaktiky chemie, kde byly samostatné studijní obory akreditovány dříve (Čtrnáctová \& Klečková, 2010; Nezvalová, 2011; Bílek, 2013). Bude zajímavé zjistit, zda nově akreditovaný obor Vzdělávání v biologii (viz tab. 1) tyto počty v budoucnu zvýší. Na závěry si budeme muset počkat, první absolventy tohoto oboru čekáme v r. 2016.

Počet autorek - žen disertačních prací je vyšší než počet autorů - mužů. Fenomén feminizace školství se tedy mírně projevuje i zde a tento trend potvrzuje i počet studentek a studentů v oboru Vzdělávání v biologii (k 30. 9. 2015 to bylo 15 osob, 9 žen a 6 mužů, tj. $60 \%$ žen a $40 \%$ mužů). Tento údaj zde uvádíme pouze pro ilustraci s vědomím, že počet studentů se nemusí nutně rovnat počtu absolventi̊. Je zajímavé, že téměř stejný poměr žen a mužů u obhájených prací byl zaznamenán Ruskem (2015) v př́padě didaktiky chemie. U didaktiky fyziky (Žák, 2015) je naopak poměr autorek i autorů obhájených prací obrácený, muži mírně převažují.

Zjištování zastoupení oborových témat ukázalo, že některá témata nejsou v pracích zastoupena vůbec (např. biologie hub). Další témata zastoupena sice byla, ale byla zkoumána pouze v jedné práci. Konkrétně se jednalo o obecnou biologii a genetiku, biologii rostlin, biologii člověka a neživou př́rodu. Absence zkoumání některých témat ale může být způsobena nízkých počtem obhájených prací vůbec. Domníváme se, že autor si většinou vybírá oborové téma, které předtím vystudoval v magisterském programu, nebo kterému se věnoval v diplomové práci. Nejčastěji zkoumanými oborovými tématy jsou biologie živočichů a ekologie.

Stupně školy zkoumané v disertacích byly zastoupeny poměrně rovnoměrně. Zde se ukazuje, že didaktika biologie má poměrně široký záběr a výrazně neopomíjí žádný stupeň školy. Vysokoškolské vzdělávání bylo přesto zkoumáno s nejvyšší četností. Jedním z důvodů může být to, že řešitelé těchto prací většinou vyučují na vysoké škole, a proto mají $\mathrm{k}$ účastníkům výzkumu snadnější přístup. Dalším důvodem může být fakt, že jsou motivováni mnohem více zkoumat vysokoškolskou edukační realitu, aby mohli výsledky svých výzkumů zavést do praxe. Svědčí o tom mimo jiné i výstupy některých prací, které nejsou výzkumné, ale ryze aplikační. V oblasti vyššího středního školství je zkoumáno především všeobecné vzdělávání, střední odborné školy jsou předmětem výzkumu jen v jedné disertační práci. Dalším zajímavým faktem je, že se všechny práce věnují pouze formálnímu vzdělávání a neformální vzdělávání není v pracích zastoupeno vůbec. Stejně tak jsme nezaznamenali žádnou práci, která by řešila problémy pomaturitního neterciárního vzdělávání (stupeň 4 podle nomenklatury ISCED97).

Použité metody sběru dat nevybočují svým charakterem od ostatních zkoumaných didaktik př́rodovědných předmětů (Rusek, 2015; Žák, 2015). Zcela jasně převažuje dotazník, který byl použit ve třech čtvrtinách prací. Tyto výsledky byly ostatně očekávány, protože dotazník patří tradičně mezi nejpoužívanější metody pedagogického výzkumu (Průcha, 2009: s. 807). Kvalita dotazníku dále zkoumána nebyla, stejně jako složení respondentů - učitelé, žáci, jiní pracovníci ve školství, tvůrci vzdělávacích programů apod. Druhou nejoblíbenější metodou je obsahová analýza, která je obvykle používána k výzkumu učebnic, Rámcových vzdělávacích programů, školních vzdělávacích programů, vzdělávacích programů a kurzů na vysokých školách, žákovských prací (esejí a portfolií). Dále bylo zaznamenáno použití pozorování, didaktického testu a interview. Jiná metoda nebyla v disertačních pracích z didaktiky biologie v uvedeném období použita.

Počet vlastních publikací, které autoři v pracích uváděli, byl značně kolísavý. Téměř v polovině prací nebyla uvedena autocitace ani jedna, což je dosti alarmující. Navíc se nedá ani konstatovat, že v průběhu let se počet publikací u disertací 
z didaktiky biologie zvyšuje a že se v této oblasti situace zlepšuje. Pokud se v některých pracích nachází vyšší počet vlastních publikací, jedná se vždy jen o ojedinělé případy. Omezením těchto závěrů může být fakt, že ne všechny své publikace autor uvedl do své disertace. Vzhledem $\mathrm{k}$ tomu, že je to jeden z ukazatelů posuzování činnosti doktoranda v průběhu celého doktorského studia, lze se domnívat, že doktorandi byli sami motivováni uvést maximum publikací souvisejících s tématem disertační práce.

Více jak polovina obhájených prací obsahuje nejrůznější výstupy do praxe, které lze považovat za jakési vedlejší produkty prací. Disertační práce by měla být primárně výzkumná (Dvořáková \& Smrčka, 2013). Je otázkou, zda autor při tvorbě tohoto výstupu nevyčerpá př́liš mnoho času a na samotný výzkum mu potom čas nezbývá. Počet vlastních publikací, které autoři v pracích uvádějí, v tomto dává za pravdu. Z provedené analýzy totiž vyplynulo, že počet vlastních publikací autora v pracích, kde lze nalézt nějaký praktický výstup, je celkově nižší než u prací bez tohoto výstupu, tedy čistě výzkumných (byt počet obhájených prací v obou skupinách není přesně identický). Faktem je, že od r. 2009 nebyla nalezena ani jedna práce obsahující podobný vedlejší produkt. Zdá se tedy, že se práce postupně svým zaměřením začínají přiklánět $\mathrm{k}$ výzkumu $\mathrm{v}$ didaktice biologie a odklánět od aplikačního pojetí, což můžeme vyhodnotit jednoznačně kladně.

Provedený výzkum nepokrývá a ani nemůže pokrývat problematiku kvality disertačních prací v celé její šiřri. Nabízí se zde proto několik potenciálních možností, jakým způsobem výzkum rozšířit a kterým oblastem se ještě věnovat. Jako další možnost, kam výzkum dále směřovat, je zkoumání, zda autoři disertací používají kvalitativní, kvantitativní nebo smíšený design výzkumu. Je možné zkoumat i správnost formulace vědeckého problému, cílů, hypotéz, výzkumných otázek. U podobně laděných analýz ovšem můžeme narazit na problém v tom smyslu, že některé z námi zkoumaných prací neměly strukturu obvyklou pro kvalifikační práce a uvedené položky se v nich daly jen těžko vysledovat a vyhodnotit. Navíc se vyskytly i práce, kde byl uváděn kromě výzkumu pedagogického i výzkum z oblasti odborné biologie nebo geologie. V neposlední řadě se jako navazující výzkumné šetření nabízí vyhodnocení adekvátních postupů při zpracování dat, např. využití statistických metod.

\section{ZÁVĚR}

Disertační práce z didaktiky biologie a geologie v letech 2004-2013 vznikaly spíše sporadicky, počet prací obhájených $\mathrm{v}$ jednom roce nepřekračoval čtyři. Byly obhájeny ve studijním programu Pedagogika, oboru Pedagogika - celkem na třech vysokých školách - Univerzita Karlova v Praze (Pedagogická fakulta), Masarykova univerzita v Brně (Pedagogická fakulta) a Univerzita Palackého v Olomouci (Pedagogická fakulta). Autory prací byly zhruba ze dvou třetin ženy a z jedné třetiny muži. Všechny práce byly napsány $\mathrm{v}$ českém jazyce. Oborová témata prací jsou nerovnoměrně zastoupena, existují tematické okruhy, které nebyly v těchto letech vůbec zkoumány (např. biologie hub). Zato zkoumané stupně škol jsou zastoupeny všechny, od preprimárního po vysokoškolský. Hlavní metodou sběru dat v pracích je dotazník, který se vyskytoval téměř ve třech čtvrtinách prací, následuje obsahová analýza dokumentu, pozorování, didaktický test a interview. Vlastní publikační aktivita autorů, posuzovaná podle počtu autocitací v disertaci, je značně kolísavá. $\mathrm{V}$ polovině prací nenajdeme citovanou ani jednu autorovu práci, ve zbylé polovině se počet pohybuje od 1 do 21 . Polovina prací obsahuje kromě výzkumné části i část aplikační, tedy nějaký praktický výstup určený pro použití v praxi. 
Zjištěná fakta bude určitě zajímavé porovnat jednak v rámci didaktik ostatních (přírodovědných) předmětů, ale i s pracemi, které budou obhajovány v následujících letech. Umožní to posoudit pozici didaktiky biologie z hlediska kvality disertačních prací mezi ostatními didaktikami, ale i posun jednotlivých parametrů v čase u tohoto oboru samotného.

\section{LITERATURA}

Bílek, M. (2013). Doktorské studium v didaktice chemie po 20 letech opět v Hradci Králové. Scientia in educatione, 4(1), 91-94.

Čtrnáctová, H. \& Klečková, M. (2010). Doktorské studium v oblasti didaktiky chemie vývoj a současnost. Scientia in educatione, 1(1), 119-124.

Dostál, P. (2010). Didaktika biologie - vývoj a současnost. Scientia in educatione, 1(1), $125-132$.

Dostál, P. (2014, ř́ijen). K historii př́pravy učitelů př́rodopisu a biologie na Pedagogické fakultě Univerzity Karlovy. Příspěvek prezentovaný na konferenci Trendy v didaktice biologie, Praha.

Dvořáková, V. \& Smrčka, J. (2013). Hodnocení kvality doktorských studijních programů na vysokých školách v ČR. Pedagogika, 63(3), 393-403.

Hendl, J. (2005). Kvalitativní výzkum: základní metody a aplikace. Praha: Portál.

Chráska, M. (2007). Metody pedagogického výzkumu. Praha: Grada.

Nezvalová, D. (2011). Didaktika fyziky v Ceské republice: trendy, výzvy a perspektivy. Pedagogická orientace, 21(2), 171-192.

Papáček, M., Čížková, V., Kubiatko, M., Petr, J. \& Závodská, R. (2015). Didaktika biologie: didaktika v rekonstrukci. In I. Stuchlíková \& T. Janík (Eds.), Oborové didaktiky: vývoj - stav - perspektivy (225-257). Brno: Masarykova univerzita.

Pavlasová, L. (2014). Přehled didaktiky biologie. Dostupné z http://vzdelavani-dvpp.eu/download/opory/02pavlasova.Kn.bl.TISK.pdf

Průcha, J. (ed.). (2009). Pedagogická encyklopedie. Praha: Portál.

Rámcový vzdělávací program pro gymnázia. (2007). Praha: VƯP. Dostupné z http://www.vuppraha.cz/wp-content/uploads/2009/12/RVPG-2007-07_final.pdf

Rámcový vzdělávací program pro předškolni vzdělávání. (2006). Praha: VÚP. Dostupné z http://www.vuppraha.cz/wp-content/uploads/2009/12/RVP_PV-2004.pdf

Rámcový vzdělávací program pro základni vzdělávání. (2013). Praha: VƯP. Dostupné z http://www.msmt.cz/vzdelavani/zakladni-vzdelavani/upraveny-ramcovy-vzdelavaciprogram-pro-zakladni-vzdelavani

Rusek, M. (2015). Analýza disertačních prací z didaktiky chemie obhájených v letech 2003-2014. Scientia in educatione, 6(2), 16-34.

Ušáková, K. (2014). Reflexia na stav a perspektivy didaktiky biologie z poh adu situacie na PRIFUK v Bratislave. Scientia in educatione, 5(2), 74-89.

Žák, V. (2015). Disertační práce z didaktiky fyziky obhájené v Ceské republice v letech 2004 až 2013 - přehled a analýza. Scientia in educatione, 6(2), 35-50. 


\section{Př́́LOHA}

Seznam analyzovaných disertačních prací

\section{Univerzita Karlova v Praze (Pedagogická fakulta)}

Andreska, Jan. Některé aspekty výuky zoologie obratlovců. 2004

Brtnová-Čepičková, Ivana. Aktivní konstrukce př́rodovědného poznání žáků primární školy. 2004

Švestková, Renata. Rozvoj ekologické výchovy v regionu. 2004

Adamcová, Ludmila. Proměny rozvíjení poznání, prvouky, přírodovědy a vlastivědy $v$ čase, ve vzdělávacím programu a v praxi. 2006

Kočí, Tomáš. Učivo, metody, organizačni formy a motivace vyučování geologii s důrazem na environment $v$ geologické historii $\breve{C} R .2007$

Pavlasová, Lenka. Praktické formy výuky v př́pravném vzděláváni učitelů přírodopisu a biologie (se zaměrením na mikrobiologii). 2007

Rajová, Štěpánka. Využití hmyzu k výuce biologie: Střevlíkovití (Coleoptera: Carabidae) Klánovického lesa a posouzení stavu jeho zachovalosti metodou bioindikace. 2007

Minář, Petr. Modernizační př́stupy v didaktice př́rodovědy, vlastivědy a prvouky při př́pravě učitelĩ primárního stupně základní školy. 2009

Dvořáková, Zuzana. Projektováni kurikula a specifikum maturitni zkoušky na střednich odborných školách. 2009

Jančaříková, Kateřina. Environmentální výchova na prvním stupni Zঙ̆. 2009

Řezníček, Jan. Analýza učebního textu „Srovnávací anatomie obratlovcü“. 2009

Pouchová, Milena. Školni projekty ve výuce př́rodovědných předmětů na 2. stupni základních škol v České republice a Slovenské republice. 2011

Šircová, Ivana. Spontánni aktivity dětí v př́rodě a předškolní výchova. 2012

Vošahlíková, Tereza. Klíčové kompetence pro udržitelné jednání v kurikulu preprimárního vzdělávání. 2012

Novotný, Petr. Určovací klíče v procesu poznávání př́rodnin. 2013

\section{Masarykova Univerzita V Brně (PEdagogickÁ FAKUlta)}

Jedličková, Helena roz. Havránková. Dynamický model zkušenostního učení ve studijním programu Učitelství pro základni školy. Inovace v př́pravě učitelů ke vzdělávání pro udržitelný rozvoj na základni škole. 2008

Hromádka, Zdeněk. Životni prostředi ve vědomostech, postojích a jednáni žáků druhého stupně základni školy. 2010 


\section{Univerzita Palackého v Olomouci (Pedagogická fakulta)}

Schovajsová, Jana. Současný stav environmentální výchovy na základních školách vybrané aspekty environmentálni gramotnosti dětí mladšího školního věku. 2010

Hlaváček, Lukáš. Statická a dynamická vizualizace ve výuce fyziologie. 2013

Pozn. K těmto pracím bychom mohli ještě přiřadit disertaci autorky Jany Přinosilové Jany s názvem Badatelsky orientovaná výuka s podporou ICT v environmentální výchově na základni škole, obhájenou v r. 2013 na katedře informačních a komunikačních technologií Pedagogické fakulty Ostravské univerzity v Ostravě v oboru Informační a komunikační technologie ve vzdělávání. Tato práce spadá oborově do didaktiky informatiky, a proto nebyla do analýzy zařazena.

LenKa PaVlasová, lenka.pavlasova@pedf.cuni.cz

Univerzita Karlova v Praze, Pedagogická fakulta

Katedra biologie a environmentálních studií

Magdalény Rettigové 4, 11639 Praha 1, Česká republika 